\title{
Perlindungan Hukum bagi Montir di Bengkel Fallen Motor Situbondo Perspektif Undang-Undang Ketenagakerjaan dan Hukum Islam
}

\author{
Muhammad Najib Amrullah ${ }^{1}$, H. Sutrisno RS ${ }^{2}$ \\ ${ }^{1}$ Fakultas Syariah, IAIN Jember. E-mail: najib9257@gmail.com \\ ${ }^{2}$ Fakultas Syariah, IAIN Jember. E-mail:h.sutrisnors12@gmail.com
}

\begin{tabular}{|c|c|}
\hline Article & Abstract \\
\hline $\begin{array}{l}\text { How to cite: } \\
\text { Muhammad Najib } \\
\text { Amrullah, H. Sutrisno RS, } \\
\text { 'Perlindungan Hukum } \\
\text { bagi Montir di Bengkel } \\
\text { Fallen Motor Situbondo } \\
\text { Perspektif Undang- } \\
\text { Undang Ketenagakerjaan } \\
\text { dan Hukum Islam' (2020) } \\
\text { Vol. } 1 \text { No. } 2 \\
\text { Rechtenstudent Journal } \\
\text { Fakultas Syariah IAIN } \\
\text { Jember. }\end{array}$ & $\begin{array}{l}\text { Human life is inseparable from law, law has an important role in the effort to create } \\
\text { conditions that enable humans to feel safe, peaceful, and their rights and existence } \\
\text { are protected. Law Number } 13 \text { of } 2003 \text { concerning Manpower regulates legal } \\
\text { protection for workers that must be fulfilled by employers as well as in Islamic law } \\
\text { which also requires the fulfilment of rights to workers following what has been done. } \\
\text { Likewise in the automotive business world, employers are obliged to protect their } \\
\text { workers. However, the Fallen Motor Workshop in Besuki sub-district, Situbondo } \\
\text { district, in the implementation of its business, neglects the rights of its workers a } \\
\text { little. The purpose of this study is to determine the legal protection regulations for } \\
\text { mechanics according to Law Number } 13 \text { of } 2003 \text { concerning Manpower and its } \\
\text { implementation of legal protection for mechanics at the Fallen Motor Workshop, } \\
\text { Besuki sub-district, Situbondo district according to the Manpower Act and Islamic } \\
\text { Law. This research is a type of qualitative research using a case approach. } \\
\text { Keywords: Legal Protection, Employment, Islamic Law. }\end{array}$ \\
\hline $\begin{array}{l}\text { Histori artikel: } \\
\text { Submit } 3 \text { April 2020; } \\
\text { Diterima } 21 \text { Juli 2020; } \\
\text { Diterbitkan } 5 \text { Agustus } \\
2020 . \\
\text { ISSN: } \\
\text { 2723-0406 (media cetak) }\end{array}$ & $\begin{array}{l}\text { Abstrak } \\
\text { Kehidupan manusia pada dasarnya tidak dapat dipisahkan dari hukum, hukum } \\
\text { mempunyai peran penting dalam upaya mewujudkan keadaan yang memungkinkan } \\
\text { manusia merasa aman, damai, serta terjaga setiap hak dan eksistensinya. Undang- } \\
\text { Undang Nomor } 13 \text { Tahun } 2003 \text { Tentang Ketenagakerjaan mengatur mengenai } \\
\text { perlindungan hukum terhadap tenaga kerja yang harus dipenuhi oleh pengusaha } \\
\text { begitupula dalam hukum Islam yang juga mengharuskan terpenuhinya hak kepada } \\
\text { pekerja sesuai dengan apa yang telah dikerjakan. Demikian juga dalam dunia usaha } \\
\text { otomotif, pemberi kerja wajib memberikan perlindungan terhadap para pekerjanya. } \\
\text { Namun Bengkel Fallen Motor di kecamatan Besuki kabupaten Situbondo dalam } \\
\text { pelaksanaan usahanya sedikit mengabaikan hak dari pekerjanya. Tujuan dari } \\
\text { penelitian ini adalah untuk mengetahui regulasi perlindungan hukum bagi montir } \\
\text { menurut Undang-Undang Nomor } 13 \text { Tahun } 2003 \text { Tentang Ketenagakerjaan dan } \\
\text { implementasinya terhadap perlindungan hukum bagi montir di Bengkel Fallen } \\
\text { Motor kecamatan Besuki kabupaten Situbondo menurut Undang-undang } \\
\text { Ketenagakerjaan dan Hukum Islam. Penelitian ini merupakan jenis penelitian } \\
\text { kualitatif dengan menggunakan pendekatan kasus (case approach). } \\
\text { Kata Kunci: Perlindungan Hukum, Ketenagakerjaan, Hukum Islam. }\end{array}$ \\
\hline
\end{tabular}

\section{Pendahuluan}

Rumah Kehidupan manusia adalah kehidupan yang pada dasarnya tidak dapat dipisahkan dari hukum. Hukum mempunyai peran penting dalam upaya mewujudkan keadaan yang memungkinkan manusia merasa aman, hidup dengan damai dan terjaga setiap hak dan eksistensinya. Dalam kehidupan sehari-hari manusia tidak dapat bertindak sesuai apa yang mereka inginkan kecuali ada hukum yang telah mengatur dalam perbuatan 
tersebut. Jadi, hukum menjadi sebuah pedoman bagi manusia dalam menjalankan aktivitasnya sehari-hari.

Dalam ketenagakerjaan di Indonesia, berdasarkan Undang-Undang Nomor 13 Tahun 2003 Tentang Ketenagakerjaan pada Bab 1 Pasal 1 angka 1 dinyatakan bahwa ketenagakerjaan adalah segala hal yang berhubungan dengan tenaga kerja pada saat waktu sebelum, selama dan sesudah masa kerja. ${ }^{1}$ Dalam kehidupan sehari-hari tentunya setiap manusia menginginkan kehidupan yang baik dan layak untuk kesejahteraan diri sendiri dan keluarganya. Hal tersebut dapat terealisasikan dengan adanya ikhtiar yang diwujudkan dalam kegiatan mencari nafkah (bekerja), karena dengan bekerja akan mendapatkan imbalan yang setimpal (upah) dan upah tersebut bisa digunakan untuk memenuhi kebutuhan hidup sehari-hari.

Pekerja atau buruh adalah seseorang yang bekerja pada orang lain (lazim disebut majikan atau pengusaha) dengan menerima upah, sekaligus mengesampingkan persoalan antara pekerjaan bebas dan pekerjaan yang dilakukan di bawah pimpinan orang lain dan mengesampingkan pula persoalan antara pekerja dan pekerja. ${ }^{2}$ Dengan demikian keadaan pekerja atau buruh keberadaannya wajib dilindungi untuk mencapai kesejahteraan bersama. Lingkup perlindungan terhadap tenaga kerja atau buruh menurut Undang-Undang Nomor 13 Tahun 2003 Tentang Ketenagakerjaan di antaranya meliputi hal mengenai pengupahan yang tertera pada Pasal 88 ayat 1 yang berbunyi setiap pekerja atau buruh berhak memperoleh penghasilan yang memenuhi penghidupan yang layak bagi kemanusiaan. ${ }^{3}$ Secara yuridis dalam hukum perburuhan, kedudukan pengusaha dan pekerja adalah sama dan sederajat. Namun, secara sosiologis pada suatu kondisi tertentu kedudukan antara pekerja dan pengusaha tidak sama dan tidak seimbang. ${ }^{4}$

Hukum Islam juga mengatur mengenai perlindungan terhadap sesama manusia, dalam hukum Islam ada beberapa firman Allah SWT yang berkaitan dengan kewajiban pembayaran upah yang seharusnya dilakukan oleh manusia khususnya pengusaha kepada pekerja atau buruh, al-Quran sebagai sumber utama hukum Islam mengandung berbagai ajaran. Mengenai firman Allah SWT tentang tuntunan memberikan upah setelah seseorang melakukan pekerjaan terdapat dalam Q.S At-Taubah ayat 105:

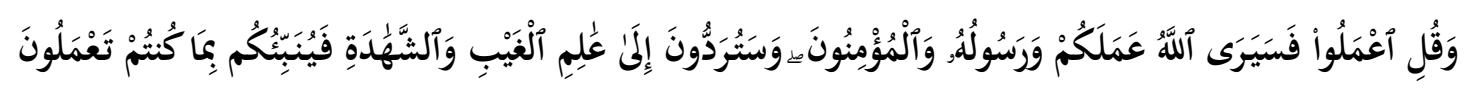

Artinya : Dan Katakanlah: “Bekerjalah kamu, maka Allah dan Rasul-Nya serta orangorang mukmin akan melihat pekerjaanmu itu, dan kamu akan dikembalikan kepada (Allah) Yang Mengetahui akan yang ghaib dan yang nyata, lalu diberitakan-Nya kepada kamu apa yang telah kamu kerjakan". (Q.S At-Taubah : 105) ${ }^{5}$

Berdasarkan ayat tersebut dijelaskan mengenai upah atau konpensasi. Jadi dalam hukum Islam, jika seseorang mengerjakan pekerjaan dengan niat karena Allah (amal shaleh), maka ia akan mendapatkan balasan, baik di dunia (berupa upah) maupun di akhirat (berupa pahala), yang berlipat ganda. Menurut penjelasan dari ayat di atas upah dalam konsep Islam

1Soedarjati, Hukum Ketenagakerjaan di Indonesia, (Yogyakarta: Pustaka Yutisia, 2008), 5.

${ }^{2}$ Halili Toha, Hubungan Kerja antara Majikan dan Buruh, (Jakarta: Rineka Cipta, 1991), 3.

${ }^{3}$ Sekretariat Negara RI, Undang-Undang Nomor 13 Tahun 2003 tentang Ketenagakerjaan.

${ }^{4}$ Fenny Natalia Khoe, “Hak Pekerja yang Sudah Bekerja Namun Belum Menandatangani Perjanjian Kerja atas Upah ditinjau Berdasarkan Undang-Undang Nomor 13 Tahun 2003 tentang Ketenagakerjaan”, Jurnal Ilmiah Mahasiswa Universitas Surabaya Vol. 2 Nomor 1, 2013, 3.

${ }^{5}$ Terjemahan Kementrian Agama RI. 
memiliki dua aspek yakni dunia dan akhirat. Jadi hal dalam pengupahan tidak hanya soal duniawi saja tapi juga tentang akhirat.

\section{Rumusan Masalah}

Adapun permasalahan yang diangkat menjadi pokok masalah sebagai berikut :

1. Bagaimana regulasi perlindungan hukum bagi montir menurut Undang-Undang Nomor 13 Tahun 2003 Tentang Ketenagakerjaan?

2. Bagaimana implementasi Undang-Undang Nomor 13 Tahun 2003 Tentang Ketenagakerjaan terhadap perlindungan hukum bagi montir di Bengkel Fallen Motor Kecamatan Besuki Kabupaten Situbondo?

3. Bagaimana implementasi perlindungan hukum bagi montir di Bengkel Fallen Motor Kecamatan Besuki Kabupaten Situbondo menurut Hukum Islam?

\section{Metode Penelitian}

Penelitian ini menggunakan jenis metode penelitian kualitatif artinya penelitian yang tidak menghasilkan angka, datanya yang diperoleh juga data yang bersifat kualitatif yang digunakan untuk mendapatkan data mendalam, suatu data yang mengandung makna yang kemudian menghasilkan sebuah kesimpulan berupa kalimat. ${ }^{6}$

Adapun pendekatan yang digunakan yaitu studi kasus, dengan menggali informasi mengenai subjek penelitian secara mendalam terkait perlindungan hukum yang didapat montir Bengkel Fallen Motor kecamatan Besuki kabupaten Situbondo. Sebagai penerapan di lapangan penelitian ini menggunakan metode pengumpulan data observasi, wawancara, dan dokumentasi. Sehingga penekanan yang dilakukan tidak hanya teori saja, mengingat penelitian kualitatif selain mengkaji teori juga harus mendapatkan fakta di lapangan.

\section{Hasil dan Pembahasan}

\section{Regulasi Perlindungan Hukum bagi Montir Menurut Undang-Undang} Ketenagakerjaan

Pola Wujud perlindungan hukum terhadap tenaga kerja khususnya montir dalam sistem ketenagakerjaan tentunya senantiasa menjadi harapan bersama, baik kepada para pelaku usaha atau majikan dan juga oleh para pekerja. Cita hukum ketenagakerjaan sebagai wadah untuk memenuhi kepentingan dan kesejahteraan bersama bagi para pihak-pihak yang terkait dalam sistem tenaga kerja itu sendiri harusnya bisa untuk diwujudkan.

Sebagaimana komitmen negara Indonesia yakni pembangunan nasional dilaksanakan dalam rangka pembangunan manusia Indonesia seutuhnya dan juga pembangunan masyarakat seluruhnya untuk mewujudkan masyarakat yang sejahtera, adil, makmur, yang merata baik materiil maupun spiritualnya berdasarkan prinsip Pancasila dan Undang-Undang Dasar Negara Republik Indonesia Tahun 1945.

Tenaga kerja mempunyai peranan dan kedudukan yang penting sebagai pelaku dan tujuan dari pembangunan nasional negara kita, oleh karena itu pemenuhan hak-hak pekerja wajib terpenuhi sebagai wujud dari pembangunan nasional tersebut. Bahwa sesuai dengan peranan dan kedudukan tenaga kerja, diperlukan pembangunan ketenagakerjaan untuk

\footnotetext{
6 Sugiyono, Metode Penelitian Pendidikan "Pendekatan kualitatif, kuantitatif dan RED" (Bandung: Alfabeta, 2011$), 13$.
} 
meningkatkan kualitas tenaga kerja dan peningkatan perlindungan hukum tenaga kerja dan keluarganya sesuai dengan harkat dan martabat kemanusiaan pada umumnya.

Perlindungan terhadap tenaga kerja dimaksudkan untuk senantiasa menjamin hak-hak dari pekerja atau buruh dan senantiasa menjamin kesamaan kesempatan serta perlakuan tanpa diskriminasi atas dasar apapun, untuk mewujudkan kesejahteraan pekerja atau buruh dan keluarganya tetap memperhatikan perkembangan kemajuan dunia usaha itu sendiri sebagaimana yang telah diatur dalam Undang-Undang Nomor 13 Tahun 2003 Tentang Ketenagakerjaan.

Berdasarkan penjelasan di atas, menunjukkan bahwa negara hadir dalam hal pemenuhan jaminan perlindungan terhadap tenaga kerja dalam bidang ketenagakerjaan, sebagai proses untuk memenuhi dan mencapai cita pembangunan nasional yakni masyarakat sejahtera, adil, makmur yang merata materiil maupun spiritualnya sebagai wujud dari nilainilai ketuhanan yang terkandung dalam Pancasila dan Undang-Undang Dasar Negara Republik Indonesia Tahun 1945.

Berkaitan dengan hal tersebut, secara teoritis perlindungan pekerja di bagi menjadi tiga jenis yaitu:

a. Perlindungan ekonomis, yaitu suatu jenis perlindungan yang berkaitan dengan usahausaha untuk memberikan kepada pekerja suatu penghasilan yang cukup untuk memenuhi keperluan sehari-hari bagi pekerja dan keluarganya, termasuk dalam hal pekerja tersebut tidak mampu bekerja karena sesuatu di luar kehendaknya, perlindungan ini disebut jaminan sosial;

b. Perlindungan sosial, yaitu suatu perlindungan yang berkaitan dengan usaha kemasyarakatan, yang tujuannya memungkinkan pekerja itu mengenyam dan mengembangkan kehidupannya sebagai manusia pada umumnya, dan sebagai anggota masyarakat dan anggota keluarga atau biasa disebut kesehatan kerja;

c. Perlindungan teknis, yaitu suatu jenis perlindungan yang berkaitan dengan usaha-usaha untuk menjaga pekerja dari bahaya kecelakaan yang dapat ditimbulkan oleh alat kerja yang dikerjakan ditempat bekerja. Selanjutnya, perlindungan jenis ini disebut dengan keselamatan kerja.

Sebagaimana tercantum dalam Pasal 86 ayat 1 Undang-Undang Nomor 13 Tahun 2003 Tentang Ketenagakerjaan disebutkan bahwa setiap pekerja atau buruh mempunyai hak untuk memperoleh perlindungan atas:

a. Keselamatan dan kesehatan kerja;

b. Moral dan kesusilaan; dan

c. Perlakuan yang sesuai dengan harkat dan martabat manusia serta nilai-nilai agama.

Untuk melindungi keselamatan pekerja atau buruh guna mewujudkan produktivitas kerja yang optimal diselenggarakan upaya keselamatan dan kesehatan kerja. Perlindungan tersebut dilaksanakan sesuai dengan peraturan perundang-undangan yang berlaku. Upah memegang peranan penting dan merupakan ciri khas suatu hubungan kerja, bahkan dapat kita katakan upah merupakan tujuan utama dari seorang pekerja melakukan pekerjaan pada seseorang atau badan hukum lain. Oleh karena itu pemerintah turut serta dalam menangani masalah pengupahan tersebut melalui berbagai kebijakan yang dituangkan dalam peraturan perundang-undangan.

Sebagaimana dalam Undang-Undang Nomor 13 Tahun 2003 Tentang Ketenagakerjaan menyebutkan setiap pekerja atau buruh berhak memperoleh penghasilan yang memenuhi penghidupan yang layak bagi kemanusiaan (Pasal 88 ayat 1 ). 


\section{Implementasi Undang-Undang Ketenagakerjaan terhadap Perlindungan Hukum} bagi Montir Bengkel Fallen Motor Situbondo

Dalam Undang-Undang Nomor 13 Tahun 2003 Tentang Ketenagakerjaan yang membahas mengenai perlindungan terhadap tenaga kerja yakni dalam Pasal 86 sampai 88, pemerintah menjamin keselamatan dan kesehatan kerja, moral dan kesusilaan, perlakuan yang sesuai dengan harkat dan martabat manusia serta nilai-nilai agama. Hal tersebut dilakukan agar para pekerja dapat dengan aman dan nyaman dalam menjalankan aktivitasnya sebagai buruh di sebuah perusahaan, baik perusahaan yang berada di bawah naungan pemerintah (BUMN) ataupun perusahaan milik perorangan atau corporate (swasta).

\section{a. Wawancara dengan pemilik Bengkel Fallen motor}

Dalam hal ini Bengkel Fallen Motor merupakan sebuah perusahaan milik perorangan yang bergerak dibidang pelayanan dan penyedia sparepart sepeda motor, seharusnya juga menerapkan Undang-Undang yang telah ditetapkan oleh pemerintah. Menurut Muhammad Yusuf (pemilik bengkel) aktivitas pekerja waktu bekerja bagi para montir ialah 7 (tujuh) jam dengan rincian jam 08.00 WIB. Para pekerja masuk, jam 12.00 WIB. Waktu istirahat untuk sholat dan makan, serta jam 16.00 WIB. Setelah para montir selesai melaksanakan tugasnya dengan mengikuti jam kerja yang telah ditentukan oleh pemilik bengkel, mereka sudah diperbolehkan untuk pulang, hal ini dilakukan karena mayoritas masyarakat besuki beragama Islam termasuk dirinya dan para pekerjanya.

Untuk waktu kerjanya kurang lebih sekitaran delapan jam mas, jam 8 pagi itu sudah masuk kerja dan mulai melakukan pekerjaannya masing-masing, jam 12 siang kita istirahat, dilanjut lagi sekitar jam 1 siang mulai bekerja lagi dan jam 4 bengkel kami sudah tutup. Kita memang menyisihkan waktu untuk istirahat karena kita manusia bukan robot yang juga memerlukan waktu untuk istirahat, biasanya waktu istirahat di isi dengan makan dan sholat. Karena kita disini semua beragama Islam termasuk saya dan istri juga orang muslim. Liburnya kita hanya hari minggu saja selain dari hari-hari besar seperti hari raya idul fitri dan idul adha, selebihnya mungkin hanya libur dihari-hari tertentu kayak tahun baru gitulah mas. Karena kalau kebanyakan libur juga mempengaruhi terhadap penghasilan tentunya.?

Mengenai upah yang diterima oleh pekerja berada diangka Rp. 900.000 (sembilan ratus ribu rupiah) perbulannya. Tentu upah tersebut di bawah upah minimum yang ada di kabupaten Situbondo, akan tetapi selain itu yang diterima para pekerja juga memiliki pemasukan dari penjualan spare part dengan hitungan persentase yakni $10 \%$ pada setiap penjualan produk spare part yang mereka jual kepada para pelanggan di luar jam kantor.

\section{b. Wawancara dengan montir Bengkel Fallen motor}

Untuk montir yang ada di Bengkel Fallen Motor berjumlah 2 (dua) orang, di antaranya Muhammad Frandika dan Rohadi Abu Bakar. Untuk mengetahui apakah pelaksanaan waktu bekerja dan pembayaran upah atau gaji yang diterangkan oleh pemilik bengkel benar adanya, selanjutnya ditanyakan mengenai hal itu kepada montir bengkel tersebut.

Saya bekerja disini untuk masuknya itu jam 8 pagi mas sampai jam 12, istirahat dari jam 12 sampai jam 1 siang saya gunakan untuk makan dan sholat, kemudian lanjut lagi sampai jam 4 sore baru pulang, kalau dihitung ya jam kerjanya 7 jam, itu sudah. Selama saya bekerja di Bengkel Fallen Motor imbalan atau gaji yang saya terima disini Rp. 900.000 (sembilan ratus

${ }^{7}$ Muhammad Yusuf, Wawancara, Situbondo 10 Maret 2020. 
ribu rupiah) dan juga mendapatkan bonus dari penjualan sparepart motor sekitar $10 \%$ selama sebulan, bonus tersebut tidak menentu tergantung hasil dari penjualan sparepart tersebut mas. Meskipun gaji tersebut tidak terlalu besar akan tetapi saya sudah bersyukur yang penting bisa untuk memenuhi kebutuhan hidup saya sehari-hari dan sedikit membantu keluarga saya mas. Daripada tidak sama sekali yang ada ini sudah disyukuri yang penting bisa untuk mengisi perut dan bertahan hidup. ${ }^{8}$

Pendapatan saya dengan bekerja sebagai montir di bengkel fallen motor ini tidak seberapa mas, akan tetapi itu sudah lumayan untuk memenuhi kebutuhan hidup saya dan keluarga saya. Upah yang saya terima selama sebulan disini Rp 900.000 (sembilan ratus ribu rupiah). Cokoplah gebey odik bik ngakan mun gun odike disah mas. Untuk jam kerja itu dari jam 8 pagi sampek jam 4 sore mas istirahatnya jam 12 sampai jam 1, seminggu masuknya 6hari liburnya hari Minggu saja, dan di hari-hari tertentu kayak Hari Raya dan Tahun Baru itu kita libur. ${ }^{9}$

Berdasarkan jawaban montir Rohadi yang menerangkan dengan gaji sebesar Rp. 900.000 (sembilan ratus ribu rupiah) itu sudah lumayan untuk memenuhi kehidupan dari montir tersebut dan keluarganya, cukup untuk bertahan hidup dan makan kalau cuma hidup di desa.

\section{c. Pembahasan Temuan}

Waktu kerja yang diatur di dalam Pasal 77 ayat 2 huruf a Undang-Undang Nomor 13 Tahun 2003 Tentang Ketenagakerjaan yang berbunyi waktu kerja untuk tenaga kerja meliputi 7 (tujuh) jam 1 (satu) hari dan 40 (empat puluh) jam 1 (satu) minggu untuk 6 (enam) hari kerja dalam 1 (satu) minggu. Sedangkan apa yang dilakukan oleh pemilik Bengkel Fallen Motor sudah sesuai dengan amanah Undang-Undang, yakni 7 jam waktu kerja dengan rincian sesuai hasil wawancara dengan pemilik bengkel jam 08:00 masuk kerja jam 12:00 sampai jam 13:00 istirahat, dan jam 16:00 tutup bengkel, sedangkan untuk hari Minggu dan hari-hari besar bengkel tidak buka.

Menurut para montir jam kerja yang diterapkan oleh pemilik bengkel sudah sesuai dengan waktu kerja pada umumnya yakni 7 jam para montir juga menyampaikan bahwa waktu kerja yang mereka dapatkan dari pemilik bengkel tidak memberatkan mereka karena selain bekerja para montir juga bisa menggunakan sisa waktu mereka untuk kegiatankegiatan yang lain.

Dalam hal pengupahan tidak adanya kesesuaian pemberian gaji kepada pekerja, yaitu montir dengan peraturan pemerintah membuat hak pekerja terabaikan, pada Pasal 89 ayat (1) Undang-Undang Ketenagakerjaan dijelaskan jika upah minimum sebagaimana dimaksud dalam Pasal 88 ayat (3) huruf a dapat terdiri atas:

1) Upah minimum berdasarkan wilayah provinsi atau kabupaten atau kota;

2) Upah minimum berdasarkan sektor pada wilayah provinsi atau kabupaten atau kota.

Dan ayat (2) yang menyatakan bahwa "upah minimum sebagaimana dimaksud dalam ayat (1) diarahkan kepada pencapaian kebutuhan hidup layak".

Berdasarkan hasil wawancara dan disesuaikan dengan Undang-Undang Nomor 13 Tahun 2003 tentang Ketenagakerjaan, pemilik Bengkel Fallen Motor tidak mengetahui mengenai pembayaran upah terhadap pekerja telah diatur dalam Undang-Undang dan harus sesuai dengan Undang-Undang dalam pembayaran upah tersebut. Sehingga dalam pemberian upah terhadap pekerja Bengkel Fallen Motor, sang pemilik hanya memberikan

${ }^{8}$ Muhammad Frandika, Wawancara, Situbondo 12 Maret 2020.

${ }^{9}$ Rohadi Abu Bakar, Wawancara, Situbondo 12 Maret 2020. 
upah semampunya dan bertentangan dengan Undang-Undang Nomor 13 Tahun 2003 Tentang Ketenagakerjaan mengenai pengupahan.

Pekerja dalam hal ini montir yang bekerja di Bengkel Fallen Motor untuk dapat memenuhi kebutuhan pribadinya dan terkadang untuk membantu kebutuhan rumah tangga, namun dalam hal upah atau gaji yang mereka terima seringkali tidak sesuai dengan beban kerja yang mereka tanggung. Namun mereka tidak memiliki keberanian untuk meminta dengan harga yang besar karena posisi mereka yang hanya sebagai montir, akan tetapi menerima upah dengan gaji yang layak merupakan salah satu hak pekerja.

Berdasarkan hasil wawancara dengan para montir Bengkel Fallen Motor gaji yang mereka terima minim untuk kebutuhan hidup mereka dan keluarga mereka, akan tetapi diusahakan cukup untuk memenuhi kebutuhan hidupnya. Montir di bengkel Fallen motor tidak mengetahui akan adanya peraturan perundang-undangan dan hukum Islam mengenai sistem pengupahan, bagi mereka bekerja yang penting mendapatkan upah dari apa yang telah mereka kerjakan untuk memenuhi kebutuhan hidup sehari-hari.

Setelah dilakukan penelitian di Bengkel Fallen Motor, terdapat pembayaran upah yang kurang layak terhadap montir di bengkel tersebut. Dalam ajaran agama Islam sudah menetapkan bahwa gaji ditentukan berdasarkan pekerjaan, mendapatkan hak gaji yang layak salah satu hak pekerja.

Keselamatan kerja di Bengkel Fallen Motor, berdasarkan hasil wawancara dengan Muhammad Yusuf selaku pemilik Bengkel Fallen Motor sudah berupaya melakukan yang terbaik untuk keselamatan terhadap pekerjanya khususnya montir, dengan menyediakan alat bantu kerja yang berupaya untuk menjaga keselamatan dari tenaga kerjanya. Selanjutnya berdasarkan dari hasil wawancara dari beberapa yang telah diuraikan pemilik Bengkel Fallen Motor tidak mengetahui atau tidak mengerti mengenai peraturan perundang-undangan khususnya Undang-Undang Nomor 13 Tahun 2003 tentang Ketenagakerjaan. Dalam praktik di lapangan meskipun pemilik Bengkel Fallen Motor tidak mengetahui terkait UndangUndang tersebut, akan tetapi Muhammad Yusuf sedikit menerapkan apa yang telah diatur dalam Undang-Undang meskipun dia tidak mengetahui akan peraturan tersebut karena dia paham mengenai apa saja yang perlu dalam pelaksanaan pekerjaan yang dilakukan pekerjanya khususnya alat bantu yang bisa digunakan untuk melindungi montir.

Dari pemaparan montir bengkel Fallen motor, memang bengkel tersebut sudah menerapkan ketentuan dalam Undang-Undang Nomor 13 Tahun 2003 Tentang Ketenagakerjaan mengenai keselamatan kerja, bahwa keselamatan dan kesehatan kerja harus diterapkan dan dilaksanakan di setiap tempat kerja karena yang bertanggung jawab atas keselamatan kerja di tempat kerja adalah pemilik usaha atau pengusaha tersebut, meskipun montir tersebut tidak mengetahui akan peraturan perundang-undangan yang melindungi mereka. Begitu pula dari beberapa hasil wawancara dengan pelanggan Bengkel Fallen Motor, bahwa pemilik bengkel sudah menyediakan alat bantu agar pekerjanya selamat dalam melakukan pekerjaannya.

\section{Implementasi Perlindungan Hukum bagi Montir di Bengkel Fallen Motor Kecamatan Besuki Kabupaten Situbondo Menurut Hukum Islam}

Dalam ajaran agama Islam, bekerja adalah kewajiban bagi setiap manusia, walaupun Allah telah menjamin rezeki setiap manusia, namun rezeki tersebut tidak akan datang kepada manusia tanpa usaha dari orang yang bersangkutan. Oleh karena itu, jika seseorang ingin 
memiliki kehidupan yang berkecukupan dan sejahtera ia harus bekerja. Dalam surat AtTaubah ayat 105 dengan tegas Allah SWT memerintahkan manusia untuk bekerja.

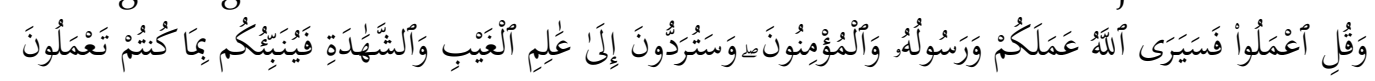

Artinya : "dan Katakanlah: "Bekerjalah kamu, maka Allah dan Rasul-Nya serta orangorang mukmin akan melihat pekerjaanmu itu, dan kamu akan dikembalikan kepada (Allah) yang mengetahui akan yang ghaib dan yang nyata, lalu diberitakan-Nya kepada kamu apa yang telah kamu kerjakan" (At-Taubah 105). ${ }^{10}$

Dan untuk konsep pengupahan dalam Islam terdapat pada surat An-Nahl ayat 97, sebagaimana berikut:

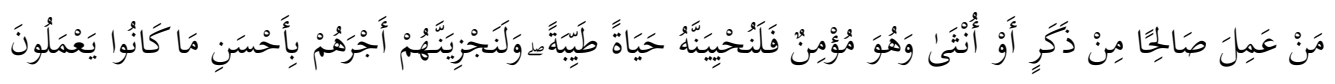

Artinya :"Barang siapa yang mengerjakan amal saleh, baik laki-laki maupun perempuan dalam Keadaan beriman, maka sesungguhnya akan Kami berikan kepadanya kehidupan yang baik dan Sesungguhnya akan Kami beri balasan kepada mereka dengan pahala yang lebih baik dari apa yang telah mereka kerjakan" (An-Nahl 97). ${ }^{11}$

Berdasarkan ayat di atas dijelaskan mengenai kebolehan kita sebagai manusia baik itu laki-laki dan perempuan untuk bekerja dan mendapat bayaran (upah) atas sesuatu pekerjaan yang telah kita lakukan. Sebagaimana dalam ayat tersebut maka imbalan dalam konsep Islam menekankan pada dua tujuan yaitu dunia dan akhirat. Tetapi hal yang paling penting adalah bahwa akhirat lebih penting daripada dunia, dalam hal ini (dalam hal materi). Pada surat AnNahl ayat 97 dijelaskan bahwa tidak ada perbedaan antara laki-laki maupun perempuan dalam menerima upah atau balasan dari Allah. Ayat ini menegaskan bahwa tidak ada diskriminasi upah dalam Islam jika mereka melakukan pekerjaan yang sama maka harus diberikan imbalan sebagai bentuk dari hasil bekerjanya.

Dalam memberikan upah kepada pekerjanya, suatu industri atau perusahaan haruslah adil dan tidak membeda-bedakan antara pekerja satu dan pekerja lainnya. Agama Islam juga menetapkan bahwa gaji ditentukan berdasarkan pekerjaan, mendapatkan hak gaji yang layak adalah salah satu hak pekerja. Di antaranya dengan memberikan hak gaji atau upah secara layak, sesuai dengan beban pekerjaan dan kemampuannya. Keselamatan dan kesehatan kerja adalah upaya perlindungan bagi tenaga kerja dan orang yang ada di sekitar lingkungan kerja selalu dalam keadaan aman, selamat, dan sehat. Suatu pekerjaan baru akan memenuhi kelayakan bagi kemanusiaan apabila perlindungan keselamatan kerja dan kesehatan kerja terjamin.

Agama Islam sangat menganjurkan keselamatan manusia baik di dunia maupun di akhirat dalam kehidupan sehari-hari, manusia tidak terlepas dari ancaman-ancaman yang membahayakan dirinya. Sebagaimana firman Allah dalam surat At-Taghabun ayat 11, yang berbunyi:

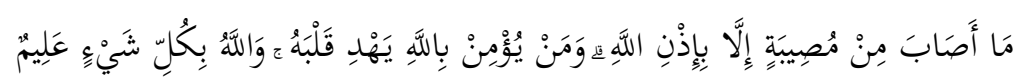

Artinya: “Tidak ada suatu musibah pun yang menimpa seseorang kecuali dengan ijin Allah, dan barangsiapa yang beriman kepada Allah niscaya Dia akan memberi petunjuk kepada hatinya. Dan Allah Maha mengetahui segala sesuatu" (At-Taghabun: 11). ${ }^{12}$

\footnotetext{
10 Terjemahan Kementerian Agama RI.

${ }^{11}$ Terjemahan Kementerian Agama RI.

12 Terjemahan Kementerian Agama RI.
} 
Jaminan keselamatan dalam Islam tidak hanya terbatas pada keselamatan badan saja, namun juga mengatur tentang keselamatan tenaga kerja yang termasuk seperti kesehatan akal, jiwa, dan agama. Dengan adanya aturan itu, dapat diciptakan sistem pekerjaan yang saling menguntungkan antara pengusaha dan pekerja, demikian Islam juga memperhatikan kepentingan-kepentingan pengusaha dan pekerja. Jaminan sosial dalam Islam memerintahkan kepada pemilik atau pengusaha (pemberi kerja) untuk berlaku adil, berbuat baik kepada para pekerjanya. Sebab para pekerja merupakan bagian dari perusahaan, dan jika pekerja bekerja dengan baik maka hasilnya pun diberikan juga untuk kebaikan bagi perusahaan.

Pada dasarnya keselamatan jiwa yang dijamin oleh pihak pengusaha adalah bertujuan untuk menciptakan keseimbangan pekerjaan. Ketika tenaga kerja selamat dari ancaman bahaya, maka akan tercipta keseimbangan dari tenaga kerja dan menghasilkan pekerjaan yang baik. Aturan mengenai hal di atas tidak bermaksud untuk memberatkan pengusaha, justru akan dapat menguntungkan kedua belah pihak. Karena dengan demikian memungkinkan menciptakan tali persaudaraan antara pengusaha dan pekerja sebagaimana manusia yang seutuhnya.

Kesehatan dan keselamatan kerja adalah bagian dari jaminan perusahaan atau yang mempekerjakan buruh yang diberikan kepada tenaga kerja. Bahaya kerja termasuk perilaku kerja yang tidak aman termasuk bahaya terhadap badan, mental, dan harta. Jadi sebagai pekerja hendaknya tidak berperilaku yang bisa membahayakan keselamatannya, dan orang yang mempekerjakan hendaknya tidak membiarkan pekerjanya terkena bahaya.

\section{Kesimpulan}

Mengenai regulasi perlindungan hukum bagi montir menurut Undang-Undang Nomor 13 Tahun 2003 Tentang Ketenagakerjaan telah jelas diatur dalam Undang-Undang tersebut sebagaimana Pasal 86 ayat 1 disebutkan bahwa setiap pekerja atau buruh mempunyai hak untuk memperoleh perlindungan atas:

a. Keselamatan dan kesehatan kerja;

b. Moral dan kesusilaan; dan

c. Perlakuan yang sesuai dengan harkat dan martabat manusia serta nilai-nilai agama.

Implementasi Undang-Undang Nomor 13 Tahun 2003 Tentang Ketenagakerjaan terhadap perlindungan hukum bagi montir Bengkel Fallen Motor di kecamatan Besuki kabupaten Situbondo, terlaksana sesuai dengan apa yang telah diatur dalam Undang-Undang ada hal yang telah diterapkan di bengkel tersebut, namun di bengkel tersebut tidak melaksanakan amanah Undang-Undang mengenai pengupahan.

Implementasi Undang-Undang Nomor 13 Tahun 2003 Tentang Ketenagakerjaan terhadap perlindungan hukum bagi montir di bengkel Fallen motor kecamatan Besuki kabupaten Situbondo menurut Hukum Islam belum sesuai dalam pengupahannya dikarenakan gaji yang diterima oleh montir kurang layak, dalam Islam juga diatur mendapatkan gaji yang layak adalah suatu hak pekerja untuk memenuhi kebutuhan dirinya dan keluarganya.

\section{Daftar Pustaka}

\section{Buku:}

Ali, Daud M. 2002. Hukum Islam. Jakarta: Raja Grafindo Persada.

Ali, Zainuddin. 2006. Pengantar Ilmu Hukum Islam di Indonesia. Jakarta: Sinar Grafika. 
Departemen Agama RI. 2014. Al-Quran dan Terjemah. Bandung: PT Diponegoro.

Sekretariat Negara RI. Undang-Undang Nomor 13 Tahun 2003 tentang Ketenagakerjaan.

Soedarjati. 2008. Hukum Ketenagakerjaan di Indonesia. Yogyakarta: Pustaka Yutisia.

Sugiyono. 2011. Metode Penelitian Pendidikan "Pendekatan Kualitatif, Kuantitatif dan RED". Bandung: Alfabeta.

Toha, Halili. 1991. Hubungan Kerja antara Majikan dan Buruh. Jakarta: Rineka Cipta. 